Online: http://journal.uny.ac.id/index.php/jppfa

\title{
MANAJEMEN BUDAYA SEKOLAH BERBASIS PESANTREN DI MADRASAH TSANAWIYAH ALI MAKSUM, SEWON, BANTUL, YOGYAKARTA
}

\author{
Lilik Ardiansyah ${ }^{1 *}$, Achmad Dardiri ${ }^{1}$ \\ ${ }^{1}$ Universitas Negeri Yogyakarta \\ ${ }^{1} \mathrm{Jl}$. Colombo No. 1, Depok, Sleman 55281, Yogyakarta, Indonesia \\ * Corresponding Author. Email: Ardisyah867@gmail.com
}

\begin{abstract}
Abstrak
Penelitian ini bertujuan untuk mendiskripsikan manajemen budaya sekolah yang ada di MTs Ali Maksum Sewon, Bantul. Penelitian ini merupakan penelitian kualitatif naturalistik dengan pendekatan kualitatif. Subjek penelitian adalah kepala sekolah, wakil kepala sekolah, tenaga pendidik, dan siswa. Data penelitian dikumpulkan melalui pengamatan langsung (observasi), analisis dokumen, dan wawancara secara mendalam. Untuk meningkatkan keabsahan data, peneliti menggunakan tehnik trianggulasi. Hasil penelitian ini adalah sebagai berikut. (1) pengembangan budaya sekolah berbasis pesantren sebagai identitas atau karakteristik madrasah dilakukan dengan berpedoman pada nilai-nilai kepesantrenan melalui sistem pendidikan dan pengajaran, yaitu kurikulum yang diterapkan dengan mengadopsi kurikulum kemenag 100\% dan kurikulum pesantren $100 \%$, dan program unggulan dan kegiatan ekstrakurikuler mampu meningkatkan motivasi belajar dan prestasi peserta didik, (2) pengelolaan budaya sekolah yang dikembangkan menyertakan peran langsung kepala madrasah dengan melakukan kegiatan manajemen yang meliputi perencanaan, pengorganisasian, motivasi, dan evalusi melalui pembentukan tim yang bertanggungjawab mengatur kegiatan, penjadwalan, koordinasi langsung dengan bawahan dan pembimbing di pondok, serta peninjauan dan pengawasan baik secara langsung maupun tidak langsung sebagai pertimbangan dalam evaluasi.
\end{abstract}

Kata Kunci: budaya sekolah, manajemen, pesantren

\section{MANAJEMEN OF PESANTREN BASED SCHOOL CULTURE AT MADRASAH TSANAWIYAH ALI MAKSUM, SEWON, BANTUL, YOGYAKARTA}

\begin{abstract}
Abtract
This research was aimed to discription the management of school culture at MTs Ali MaksumSewon, Bantul. This was qualitative naturalistic research using the qualitative approach. The research subjects were the headmaster, deputy headmaster, teachers, and students. The data were gathered through three main direct observation, document analysis, and in-depth interview. To develop the data validity, the researcher used the triangulation technique. The research results were as follows. (1) The development of pesantren-based school culture as a madrasah identity and characteristic was conducted based on Islamic school of Koranic studies values through educational and teaching system, curriculum applied by adopting the curriculum of Kemenag $100 \%$ and curriculum of pesantren $100 \%$ as well as excellent programs and extracurricular activities which were able to improve students learning motivation and achievement. (2) The management of school culture was developed by involving direct roles of madrasah principal by performing management activities that covered planning, organizing, motivation and evaluation through establishment team that was responsible to handle activities, scheduling, direct coordination with subordinates and instructors in school and direct and indirect observation and supervision as an observation in evaluation.
\end{abstract}

Keywords: school culture, management, pesantren (Islamic school) 


\section{PENDAHULUAN}

Pendidikan merupakan suatu hal yang sangat urgen dan pokok bagi kehidupan manusia. Melalui pendidikan, akan menciptakan sumber daya manusia yang berkualitas. Maju mundurnya peradaban suatu bangsa bergantung pada kualitas sumber daya manusianya yang dapat dicetak melalui pendidikan. Pentingnya pendidikan bagi kemajuan peradaban bangsa juga disadari oleh pemerintah dengan dikeluarkannya Undang-undang Nomor 20 Tahun 2003 tentang Sistem Pendidikan Nasional (Presiden Republik Indonesia, 2003) yang menekankan arti penting pendidikan sebagaimana termuat dalam Pasal 3 Undangundang tersebut:

"Pendidikan Nasional berfungsi mengembangkan kemampuan dan membentuk watak serta peradaban bangsa yang bermartabat dalam rangka mencerdaskan kehidupan bangsa, bertujuan untuk berkembangnya potensi peserta didik agar menjadi manusia yang beriman dan bertaqwa kepada Tuhan Yang Maha Esa, berakhlak mulia, sehat, berilmu, cakap, kreatif dan menajdi warga negara yang demokratis serta bertanggungjawab."

Pasal tersebut menegaskan bahwa, pada dasarnya pendidikan bertujuan untuk membentuk masyarakat Indonesia sebagai manusia yang berkualitas, yaitu manusia yang sadar akan hak dan kewajibannya dan bertanggung jawab terhadap bangsa dan negaranya. Hal ini berarti bahwa, tujuan pendidikan adalah untuk memanusiakan manusia menjadi manusia yang bermartabat dan berkebudayaan.

Peran pendidikan dalam pengembangan kualitas sumber daya manusia dapat dilihat dari beberapa dimensi fungsi pendidikan, yaitu pendidikan sebagai alih fungsi iptek, alih sistem nilai dan berfungsi untuk meningkatkan produktivitas nasional (Kementerian Pendidikan dan Kebudayaan Republik Indonesia, 2014). Fungsi pendidikan sebagai alih sistem nilai mengarah pada sasaran bah-wa produk pendidikan di samping mempunyai pengetahuan, juga kepribadian yang berciri khas Indonesia dan tetap menjunjung tinggi nilai-nilai budaya yang luhur. Selanjutnya, pada era globalisasi yang memusatkan kegiatan pada pemanfaatan teknologi ini, manusia dituntut memiliki pola pikir dan sikap yang cerdas agar tidak mengarah pada penyalahgunaan
IT dan tetap dalam bingkai tujuan pendidikan, yaitu mencetak manusia yang berilmu dan berakhlak mulia.

Kualitas sumber daya manusia yang dihasilkan oleh suatu lembaga pendidikan merupakan penentu tinggi rendahnya mutu pendidikan. Mutu atau kualitas pendidikan sangat ditentukan oleh input peserta didik yang ditunjukkan oleh potensi peserta didik, mutu pengalaman belajar yang ditentukan oleh kemampuan profesional guru, mutu penggunaan fasilitas belajar dan budaya sekolah yang merupakan refleksi mutu kepemimpinan kepala sekolah.

Telah diakui, bahwa budaya sekolah menjadi salah satu kriteria penentu mutu atau kualitas pendidikan. Hal ini juga diakui oleh Pamuji \& Prasojo (2013, p. 3) bahwa budaya sekolah menjadi salah satu faktor penting dalam menentukan keberhasilan mutu pendidikan, khususnya dalam upaya meningkatkan kedisiplinan siswa. Namun demikian, kondisi di lapangan menunjukkan yang lain. Masih ada beberapa sekolah yang belum mampu mengelola budaya sekolah dengan baik, sehingga budaya sekolah yang sudah tertanam sejak lama tidak berjalan dengan baik dan perlahanlahan akan mulai memudar.

Budaya sekolah pada hakekatnya merujuk pada sistem nilai, kepercayaan dan norma-norma yang diterima secara bersama, serta dilaksanakan dengah penuh kesadaran sebagai perilaku alami yang dibentuk oleh lingkungan tersebut. Budaya sekolah berkaitan erat dengan pembentukan suasana sekolah yang kondusif. Budaya sekolah akan berjalan dengan baik, apabila: (1) memusatkan fokus pembelajaran pada hasil belajar peserta didik: (2) menjamin keseimbangan antara kegiatan belajar individual, kolaborasi dan belajar dalam interaksi sosial; (2) selaras dengan kebutuhan pengembangan motivasi peserta didik; (3) sensitif terhadap perbedaan individu; (4) menantang peserta didik dengan tidak memberikan lebih dari kapasitasnya. (Kementerian Pendidikan dan Kebudayaan Republik Indonesia, 2014, p. 73)

Pengembangan dan pengelolaan budaya sekolah yang baik, dapat menciptakan suasana sekolah yang kondusif, membangun hubungan yang harmonis untuk menunjang terbentuknya norma, keyakinan, sikap, karakter dan motivasi yang tinggi untuk berprestasi. Dengan demikian, pengembangan budaya se- 
kolah di sekolah perlu dilaksanakan di sekolah demi kemajuan sekolah. Budaya sekolah yang dikembangkan akan menjadi ciri khas atau karakteristik suatu sekolah yang sering dijadikan sebagai identitas sekolah yang diketahui dan dipahami oleh seluruh warga sekolah, sehingga budaya sekolah dapat meningkatkan mutu pendidikan. Budaya sekolah menjadi karakteristik suatu sekolah, sehingga upaya pengembangannya perlu dipahami agar nilai-nilai yang dikembangkan sebagai budaya sekolah diyakini dan dijadikan sebagai pola perilaku yang menjadi kendali dalam membentuk sikap dan perilaku warga sekolah.

MTs Ali Maksum merupakan sekolah yang sederajat dengan jenjang sekolah menengah pertama dengan basis pesantren. Nilainilai kepesantrenan pun tidak luput dimasukkan di lembaga pendidikan tersebut. Hal ini-lah yang menjadi salah satu pembeda MTs Ali Maksum dengan sekolah-sekolah lainnya. Para siswa merupakan santri Pondok Pesantren Ali Maksum yang gerak-geriknya dalam pengawasan para pembimbing. MTs Ali Maksum merupakan lembaga pendidikan di bawah Yayasan Pondok Pesantren Ali Maksum, sehingga nilai-nilai dan karakter yang dibangun di madrasah ini tidak lepas dari pengurus yayasan. Berdasarkan uraian yang disampaikan tersebut maka penelitian ini bertujuan untuk mendiskripsikan manajemen budaya sekolah yang ada di MTs Ali Maksum Sewon, Bantul.

\section{METODE PENELITIAN}

Penelitian ini merupakan penelitian jenis naturalistik dengan pendekatan kualitatif yakni penelitian yang mendasarkan pada kondisi obyek yang alamiah, sesuatu yang dinamis, hasil konstruksi pemikiran, dan utuh yakni mempunyai satu kesatuan yang tidak dapat dipisahkan.

Dalam penelitian ini instrumen utama adalah peneliti sendiri. Akan tetapi setelah fokus penelitian menjadi jelas, peneliti mengembangkan isntrumen penelitian sederhanan dengan harapan dapat digunakan untuk menjaring data pada sumber data yang lebih luas, dan mempertajam serta melengkapi data hasil pengamatan dan dokumentasi.

Dalam penelitian ini instrumen yang dibuat adalah instrument fisik, pelaku, disiplin, tata tertib, kerja keras, toleransi, peranan warga sekolah serta faktor-faktor yang menghambat pelaksanaan budaya sekolah.

Penelitian ini dilakukan di MTs Ali Maksum, Krapyak, Yogyakarta mulai bulan November sampai bulan Desember 2016. Pemilihan lokasi penelitian ini didasarkan pada alasan karena sekolah ini merupakan sekolah tua yang mempunyai basis pesantren dan mempunyai budaya sekolah yang berbeda dengan sekolah lainnya, kebiasaan-kebiasaan dalam dunia pesantren dan dunia pendidikan mempunyai ciri yang berbeda dengan sekolah lainnya. Hal ini juga bisa digunakan sebagai tolok ukur budaya sekolah yang baik. Hal ini menjadi alasan utama untuk memilih MTS Ali Maksum sebagai lokasi penelitian.

Subjek penelitian merupakan sumber untuk memperoleh keterangan penelitian. Adapun subjek yang menjadi sumber data dalam penelitian ini adalah: (1) Kepala sekolah selaku pihak yang bertanggung jawab atas seluruh kegiatan pengembangan budaya sekolah, (2) Wakil kepala sekolah sebagai pihak yang membantu kepala sekolah dan bertanggung jawab atas wewenang yang dilimpahkan kepala sekolah, (3) Guru selaku pendidik yang berhadapan langsung dengan peserta didik, (4) Penanggung jawab program selaku pihak yang bertanggung melaksanakan program yang telah direncanakan.

Dalam penelitian ini uji keabsahan data meliputi credibility, transferability, dependability, dan confirmability.

Uji kredibilitas data atau kepercayaan terhadap data hasil penelitian dilakukan dengan perpanjangan pengamatan dan triangulasi. Perpanjangan pengamatan berarti kembali ke lapangan, melakukan pengamatan, wawancara lagi dengan nara sumber yang pernah ditemui maupun yang baru. Sedangkan triangulasi diartikan sebagai pengecekan data dari berbagai sumber dengan berbagai cara, dan berbagai waktu.

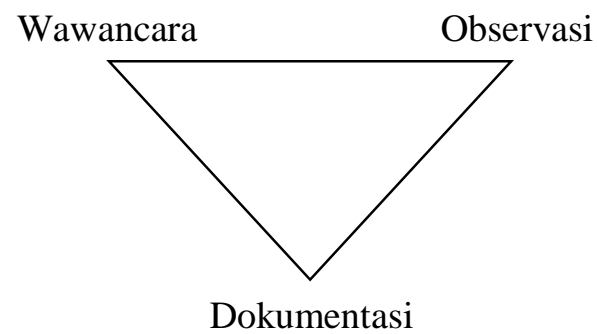

Gambar 1. Triangulasi Teknik Pengumpulan Data 
Uji transferability dilakukan supaya orang lain dapat memahami hasil penelitian sehingga ada kemungkinan untuk menerapkan hasil penelitian tersebut, maka peneliti dalam membuat laporan harus memberikan uraian yang rinci, jelas, sistematis, dan dapat dipercaya.

Dependability dilakukan dengan melakukan audit terhadap keseluruhan proses penelitian. Caranya dilakukan oleh auditor yang independen, atau pembimbing untuk mengaudit keseluruhan aktivitas peneliti dalam melakukan penelitian. Bagaimana peneliti mulai menentukan masalah/fokus, memasuki lapangan, menentukan sumber data, melakukan analisis data, melakukan uji keabsahan data, sampai membuat kesimpulan harus dapat ditunjukan oleh peneliti. Jika peneliti tidak mampu menunjukkan "jejak aktivitas lapangannya", maka reliabilitas penelitiannya patut diragukan.

Menguji comfirmability berarti menguji hasil penelitian, dikaitkan dengan proses yang dilakukan. Bila hasil penelitian merupakan hasil dari proses penelitian yang dilakukan, maka penelitian tersebut telah memenuhi standar comfirmability. Dalam penelitian, jangan sampai proses tidak ada, tetapi hasilnya ada.

\section{HASIL PENELITIAN DAN PEMBAHASAN}

Pada bagian ini akan dipaparkan hasil penelitian yang telah dilakukan oleh peneliti selama kurang lebih 2 (dua) bulan terjun ke lapangan yaitu bulan November sampai dengan Desember 2016. Pemaparan hasil penelitian akan dirangkum dalam 3 tema besar, yaitu pengembangan budaya sekolah berbasis pesantren di MTs Ali Maksum, manajemen budaya sekolah berbasis pesantren di MTs Ali Maksum, dan kendala yang dihadapi pihak MTs Ali Maksum dalam mengembangkan budaya sekolah. Selanjutnya hasil penelitian akan dipaparkan sebagai berikut:

\section{Pengembangan Budaya Sekolah Berbasis Pesantren di MTs Ali Maksum}

MTs Ali Maksum Krapyak Yogyakarta merupakan salah satu lembaga pendidikan formal dalam lingkungan Yayasan Ali Maksum Pondok Pesantren Krapyak Yogyakarta yang bertanggungjawab kepada Kantor
Wilayah Kementerian Agama. Keyakinan masyarakat pesantren adalah bahwa mereka merupakan bagian umat utama yang mengokohkan landasan keyakinan madrasah sebagai lembaga dari, oleh, dan untuk kelompok umat terbaik, yaitu kyai-guru pendidik dan santrisiswa, bagi masyarakat pesantren khususnya dan masyarakat global umumnya.

MTs Ali Maksum merupakan madrasah swasta berbasis pesantren dengan keberadaannya di Indonesia. Dalam satu waktu yang sama, peserta didik di MTs Ali Maksum sekaligus menyandang status sebagai santri Pondok Pesantren Ali Maksum. Hal ini dikarenakan peserta didik di MTs Ali Maksum juga merupakan santri di pondok. Peserta didik 100\% berdomisili di pondok, yang gerak gerik sikapnya akan diawasi baik oleh bapak/ibu guru, pembimbing, maupun pengasuh selama 24 jam. Sikap peserta didik yang sudah di luar batas kontrol akan mendapat penanganan dengan sesegera mungkin. Hal ini untuk menghindari dampak sikap peserta didik tersebut meluas ke peserta didik lainnya.

Identitas dan ciri tersebut merupakan penampakan dari visi dan misi yang didasarkan atas nilai-nilai pendidikan pesantren yang teguh sekaligus luwes dengan perkembangan yang terjadi pada masyarakat. Jati diri MTs Ali Maksum sebagai madrasah dengan basis pesantren semakin berbeda karena menerapkan ciri-khas konvergensi dalam kurikulumnya. Dalam pola ini, madrasah masih mempertahankan muatan lokal kepesantrenan, disamping mengadopsi Kurikulum Nasional Pendidikan maupun dari Kementerian Agama. Demikian pula karakter kuat madrasah pesantren terlihat dari pola keterpaduan dalam kurikulum dan pengelolaan proses pembelajarannya.

Nilai-nilai kepesantrenan dimasukkan ke dalam kurikulum yang dipadukan dengan proses pembelajaran. Dalam hal ini, kebijakan-kebijakan yang ditetapkan baik berkenaan dengan pendidikan, pengajaran maupun kurikulumnya didasarkan pada usaha secara maksimal dari visi dan misi Madrasah Tsanawiyah yang mempunyai otonomi pendidikan.

Sebagai lembaga pendidikan formal dengan basis pesantren yang sudah berdiri setengah abad yang lalu, nilai-nilai yang diyakini maupun budaya yang dikembangkan banyak mengadopsi dari pesantren sebagai berikut: Budaya salaman pagi, amalan asmaul husna, budaya bersih dan peduli lingkungan, 
budaya disiplin, budaya membaca dan menulis, musyawarah malam, pemisahan ruang putra dan putri, budaya prestasi (program keterampilan dan seni, kegiatan ektrakulikuler).

\section{Manajemen Budaya Sekolah Berbasis Pesantren di MTs Ali Maksum}

Manajemen budaya sekolah merupakan proses pengelolaan sumber daya yang ada untuk mencapai tujuan dan sasaran yang telah ditetapkan. George R. Terry (Engkoswara \& Komariah, 2010, p. 87) mendiskripsikan manajemen sebagai berikut "Management is a distinct process consisting of planning, organizing, actuating, and controllin, performed to determine and accomplish stated objectives by use human being and other resources". Manajemen adalah suatu proses khas yang terdiri dari perencanaan, pengorganisasian, pelaksanaan, dan pengawasan yang dilakukan untuk menentukan dan meyelesaikan tujuan melalui manusia dan sumber-sumber yang lainnya.

Penelitian ini berlatar belakang belum dilaksanakannya nilai-nilai budaya yang dikembangkan di MTs Ali Maksum oleh seluruh civitas akademika madrasah. Hal ini berakibat pada belum optimalnya implementasi budaya madrasah yang banyak mengadopsi dari pesantren dan disesuaikan dengan karakteristik sekolah dalam rangka mewujudkan visi sekolah sebagai madrasah berbasis pesantren utama. Mengacu pada fungsi-fungsi manajemen yang dikembangkan oleh George Terry, yakni seperti berikut:

\section{Perencanaan Program}

Perencanaan merupakan bagian yang sangat penting dalam pengembangan dan pembentukan budaya sekolah di MTs Ali Maksum. Melalui proses perencanaan ini budaya sekolah yang dikembangkan di MTs Ali Maksum mulai dikelola secara baik. Budaya yang dikembangkan diselaraskan sesuai dengan misisnya untuk mewujudkan visi sebagai madrasah berbasis pesantren utama. Dalam hal ini, ilmu pengetahuan dan ilmu agama disandingkan secara bersamaan untuk mewujudkan peserta didik yang ilmuan, bahasawan, dan agamawan. Oleh karena itu, budaya yang dikembangkan melalui beberapa program selalu memuat nilai-nilai agama/kepesantrenan. Hal ini sesuai dengan pendapat Barnawi (2013, p. 43) bahwa unsurunsur budaya sekolah mencakup 2 (dua) kate- gori, yaitu unsur tidak kasat mata dan unsur tidak kasat mata.

Fungsi perencanaan yang menjadi bagian dari manajemen dilaksanakan melalui perumusan program-program yang dapat mendukung terwujudnya visi, misi, dan tujuan madrasah. Perumusan nilai-nilai dan norma kepesantrenan maupun non kepesantrenan menjadi program sekolah dilakukan oleh kepala madrasah beserta jajaran wakil kepala sekolah. Menurut Lukman Hakim (wawancara pada 14 November 2016), Nilai-nilai dan norma yang dirumuskan bersama menjadi budaya sekolah tidak dapat dilepaskan dari norma kepesantrenan. Misalnya, adanya ketentuan ujian pesantren sebagai syarat naik kelas.

Perencanaan program yang sudah disepakati sebagaimana telah diuraikan di bagian pertama tentang pengembangan budaya sekolah berbasis pesantren akan diorganisir dengan menyusun perencanaan target dan membentuk tim yang meliputi koordinator, pengawas lapangan, dan tentor dengan tugasnya masingmasing. Perencanaan target memuat semacam kurikulum yang berisi materi dan target ketercapaian program dalam jangka satu atau dua semester berjalan. Setiap kegiatan atau program yang telah direncanakan akan diorganisir dengan menyusun jadwal piket atau penanggung jawab, sehingga kepala madrasah akan dengan mudah dalam melakukan kontrol atau pengawasan.

Unsur tidak kasat mata adalah falsafah atau pandangan dasar madrasah mengenai kenyataan yang luas dan harus diperjuangkan, yaitu keyakinan tentang nilai-nilai luhur kepesantrenan sebagaimana dalam Al Qur'an dan Hadis, khususnya surat at-Taubah, al-Mujadalah, dan Hadist. Keyakinan tersebut menekankan bahwa mereka adalah bagian umat utama mengokohkan landasan keyakinan Madrasah Tsanawiyah sebagai lembaga dari, oleh, dan untuk kelompok umat terbaik yakni kyai-guru pendidik dan santri-peserta didik, bagi masyarakat pesantren khususnya dan masyarakat global umunya. Unsur tidak kasat mata termanifestasi secara konseptual dalam visi, misi, tujuan, dan sasaran yang lebih konkret yang akan dicapai oleh madrasah.

\section{Pengorganisasian Program}

Pengorganisasian adalah suatu kegiatan penentuan dan pembagian tugas, tanggung jawab dan wewenang terhadap kegiatan ter- 
tentu, sehingga program atau kegiatan yang telah direncanakan dapat terlaksana secara efektif dan efisien. (Engkoswara \& Komariah, 2010, p. 95) menyebutkan kegiatan yang dilakukan dalam proses pengorganisasian, seba-gai berikut: (1) menentukan sumber daya dan kegiatan yang dibutuhkan untuk mencapai tujuan organisasi, (2) merancang dan mengembangkan kelompok kerja yang berisi orang yang mampu membawa organisasi pada tujuan, (3) menugaskan seseorang atau kelompok orang dalam suatu tanggung jawab tugas dan fungsi tertentu, (4) mendelegasikan wewenang kepada individu yang berhubungan dengan keleluwasaan melaksanakan tugas.

Pengorganisasian budaya sekolah di MTs Ali Maksum dilakukan oleh kepala sekolah yang dibantu oleh staff yang ada dibawahnya. Kepala sekolah bertanggung jawab penuh terhadap semua program pembentukan dan pengembangan budaya belajar yang ada di MTs Ali Maksum. Kepala sekolah juga telah berusaha menciptakan suasana kerja yang jelas melalui pembentukan struktur tugas yang jelas, sehingga setiap bidang yang ada memiliki kejelasan arah dan langkah. Sebagaimana pendapat Robbin (1996, p. 294), bahwa budaya sekolah juga dapat meningkatkan kemantapan sistem sosial yang mampu mempersatukan anggota kelompok yang memiliki berbagai macam karakteristik dan latar belakang. Madrasah bekerjasama dengan pondok untuk mempersatukan perbedaan-perbedaan peserta didik melalui kegiatan yang dapat menciptakan suasana kebersamaan, misalnya dengan mengaji dan bermusyawarah bersama. Peserta didik dibiasakan untuk saling menghormati dan menghargai dalam segala perbedaan. Dalam komunikasi sehari-hari, bahasa persatuan yaitu Bahasa Indonesia menjadi pemersatu. Hal ini sebagaimana dikemukakan oleh Ahmad Hanis Thoriq saat wawancara pada 7 November 2016, bahwa "Upaya sekolah untuk mempersatukan segala perbedaan latar belakang peserta didik adalah melalui penggunaan Bahasa Indonesia dalam berkomunikasi. Selain itu, madrasah juga memberikan motivasi kepada peserta didik melalui guru maupun BK".

Di sebuah lembaga pendidikan yang di dalamnya dipimpin oleh seorang kepala sekolah/madrasah, ketika melakukan evaluasi program yang tidak berjalan, tentunya harus mampu mengambil suatu kebijakan untuk menata dan mengelola kembali program tersebut. Sa- lah satu fungsi kepala sekolah/madrasah dalam menjalankan perannya adalah sebagai manajer. Seorang manajer harus mampu melaksanakan fungsi manajemen, yang meliputi perencanaan, pengorganisasian, motivasi, dan melakukan kontrol atau evaluasi atas pelaksanaan pendidikan di sekolah. Manajer adalah seseorang yang mempunyai tugas untuk membina dan mengembangkan sumber daya manusia, dan mengendalikan agar organisasi dapat mencapai tujuan yang telah ditetapkan. Kepala sekolah MTs Ali Maksum melakukan koordinasi kegiatan, khususnya yang berkaitan dengan program dan kegiatan pembentukan dan pengembangan budaya sekolah.

\section{Pelaksanaan Program}

Pelaksanaan merupakan kegiatan untuk mewujudkan program dan kegiatan yang telah direncanakan. Berdasar rumusan yang ada dan telah disepakati sebagai program yang dikembangkan di madrasah, maka guru, peserta didik, dan seluruh civitas akademika MTs Ali Maksum harus melaksanakan kebijakan yang telah disepakati. Namun demikian, karena guru tidak semua dilibatkan dalam merumuskan program sekolah, sering terjadi guru yang mengeluhkan program dan bekerja dengan terpaksa. Hal ini memperlihatkan bahwa budaya demokratis yang menerapkan sistem musyawarah dalam setiap pengambilan keputusan belum dilaksanakan secara optimal, karena bagaimanapun juga guru adalah sebagai pelaksana teknis.

Budaya sekolah akan lebif efektif dan optimal apabila dibuat atau disusun dengan mempertimbangkan ahli-ahli dari sebuah konteks, yang meliputi para guru, peserta didik, orang tua, dan masyarakat setempat, serta pihak yang berkepentingan lainnya. Hal ini dengan tujuan agar pengambangan budaya sekolah benar-benar dapat dilaksanakan oleh pihak-pihak yang bersangkutan, sehingga akan mendukung terwujudnya tujuan sekolah. Hal ini selaras dengan pendapat Hongboontri \& Keawkhong (2014), "School cultures are unique and distinctive. They are created and re-created by people considered members of a context: teachers, parents, and communities, among many others."

Selain itu, dalam melakukan pengelolaan budaya sekolah, kepala sekolah memberikan evaluasi dan terjun secara langsung 
untuk melakukan kontrol atas penyelenggaraan program. Setiap hari pada jam pulang sekolah, kepala sekolah akan memanggil perwakilan masing-masing kelas untuk meminta informasi pelaksanaan kegiatan pembelajaran yang telah berlangsung pada hari itu: "Kepala sekolah memberi evaluasi dan terjun langsung, serta anak-anak hampir setiap kelas laporan setiap hari mengenai kegiatan pembelajaran yang telah dilaksanakan pada hari itu. Hal ini dimaksudkan untuk mengontrol kegiatan pembelajaran, baik dari sisi guru maupun peserta didiknya sendiri," (Zaky Muhammad, wawancara pada 7 November 2016).

Pelaksanaan kegiatan maupun program dilakukan melalui penyusunan struktur organisasi berdasarkan sumber daya yang dimiliki dan lingkungan yang melingkupinya, dengan sekaligus pengalokasian sumber daya keuangan untuk menunjang lancarnya kegiatan. Tujuan pengorganisasian ini selaras dengan pendapat Handoko (2013, p. 62), yaitu untuk mengatasi terbatasnya kemampuan, kemauan, dan sumber daya yang dimiliki, sehingga perlu adanya pembagian tugas untuk mendorong dan meningkatkan kerjasama. Selain itu, melalui pengorganisasian akan mempermudah suatu organisasi dalam mencapai tujuan secara lebih efektif dan efisien, karena tanggung jawab bersama akan dikerjakan secara bersama-sama dengan penuh semangat gotong royong (motif pencapaian tujuan).

Fungsi kepala sekolah/madrasah dalam menjalankan perannya adalah kemampuan untuk memberikan pengarahan atau motivasi. Seorang kepala sekolah/madrasah akan selalu berupaya untuk menjalin komunikasi yang baik melakukan koordinasi terhadap bawahan agar dalam menjalankan tugas dan tanggung jawabnya selalu dalam satu pandangan dan menghindari adanya mis komunikasi. Motivasi, semangat, dan dorongan selalu diberikan oleh kepala madrasah, baik kepada guru dengan mengingatkan tugas mulianya maupun kepada peserta didik.

Koordinasi dilakukan oleh kepala madrasah terhadap bawahan untuk mengetahui ketercapaian target yang sudah dicapai dan menjaring kendala yang dihadapi oleh bawahan dalam menjalankan tugasnya. Dalam hal demikian, kepala madrasah akan berusaha memberikan masukan ataupun turut memberikan solusi atas kendala yang dihadapi oleh bawahan, sehingga tujuan dapat tercapai sebagaimana yang ditargetkan.

Setiap kegiatan atau program yang telah dilaksanakan agar pelaksanaannya tetap selaras terhadap tujuan, seorang kepala sekolah/madrasah akan selalu melakuan pengawasan. Pengawasan dilakukan melalui proses pemantauan baik langsung maupun tidak langsung, penilaian, maupun pelaporan atas ketercapaian target tujuan yang telah ditetapkan sebagai tindakan koreksi guna penyempurnaan lebih lanjut dan meminimalisir adanya penyimpangan atau penyelewengan.

Kepala madrasah secara periodik melakukan koordinasi langsung terhadap bawahan yang telah diberikan tugas dan tanggung jawab untuk menghandle suatu kegiatan atau program terkait progres program apakah sudah berjalan sesuai dengan harapan atau belum. Evaluasi bulanan tentang progres dari program dilakukan secara intern oleh kepala madrasah beserta jajaran wakil kepala madrasah. Selanjutnya hasil evaluasi bulanan oleh kepala madrasah beserta jajarannya akan disampaikan dalam forum rapat bulanan dewan guru dan pegawai. Tidak hanya itu, kepala madrasah juga melakukan observasi ke kelas atau ke tempat dilaksanakannya program untuk memantau secara langsung.

Kepala madrasah juga menjaring informasi progres atas program madrasah dari peserta didik secara langsung untuk mendapatkan informasi yang sinkron dan kredibel. Kepala madrasah akan memanggil perwakilan setiap kelas secara bergiliran untuk menghadap kepala madrasah melaporkan kegiatan atau kejadian yang telah terjadi di ruang kelas atau di tempat dilaksanakannya program. Komunikasi ini dilakukan intern antara kepala sekolah dengan perwakilan masing-masing kelas sebagai bahan pertimbangan evaluasi selanjutnya.

\section{Pengendalian (Evaluasi) Program}

Pengendalian program merupakan usaha untuk menjamin pelaksanaan program dan kegiatan sesuai dengan yang telah direncanakan. Untuk meningkatkan efektivitas pengendalian atau pengawasan budaya sekolah setiap bidang saling berkoordinasi. Program pengembangan budaya sekolah di MTs Ali Maksum dikendalikan oleh masing-masing penanggung jawab. Setiap penanggung jawab melakukan evaluasi terhadap proram yang telah dilaksanakan. Dari hasil evaluasi tersebut 
dijadikan sebagai dasar dan bahan masukan bagi manajemen untuk menyusun program selanjutnya.

Di bidang program unggulan, evaluasi dilakukan melalui jaring aspirasi. Program jaring aspirasi dilakukan oleh OSIS MTs Ali Maksum di bawah bimbingan wakil kesiswaan. Kegiatan ini dilakukan untuk mejaring segala permasalahan yang muncul dalam proses kegiatan dan belum mendapat penanganan. Program jaring aspirasi juga dimaksudkan untuk menampung usulan atau masukan dari semua pihak untuk meningkatkan kualitas program pengembangan budaya sekolah di MTs Ali Maksum.

\section{Kendala Pengembangan Budaya Sekolah Berbasis Pesantren di MTs Ali Maksum}

Nilai-nilai yang dikembangkan menjadi budaya sekolah di MTs Ali Maksum melalui program madrasah dalam pelaksanaannya tentu tidak pernah lepas dari kendala. Kendala bisa saja muncul dari madrasah sendiri, baik yang berasal dari kepala madrasah, guru/ pegawai, atau peserta didik, maupun kendala yang tidak dapat dihindari yang berasal dari luar madrasah, yaitu berasal dari masyarakat atau kondisi lingkungan sekitar.

Berdasarkan wawancara yang telah dilaksanakan, didapatkan hasil bahwa budaya sekolah yang diinternalisasi menjadi program madrasah sudah dilaksanakan, meskipun secara keseluruhan masih jauh dari target karena adanya berbagai kendala walaupun sejauh ini tidak ada pihak yang menentang atas pelaksanaan program. Adapun kendala yang dihadapi oleh pihak MTs Ali Maksum dalam mengembangkan budaya sekolah adalah sebagai berikut; (1) Kesadaran peserta didik maupun guru masih rendah dalam melaksanakan program. Rendahnya kesadaran peserta didik maupun guru dalam melaksanakan program berakibat pada belum optimalnya pelaksanaan program; (2) Khusus mengenai program unggulan, sarana prasarana masih belum memadai karena masih tergolong program baru, sehingga masih perlu banyak persiapan khususnya kelengkapan sarana prasarana. Kurangnya sarana prasarana ini berakibat pada terkendalanya pelaksanaan program, sehingga pelaksanaannya belum optimal; (3) Komunikasi dan koordinasi antara pihak madrasah (khususnya guru) dengan pembimbing pondok masih kurang. $\mathrm{Ku}-$ rangnya komunikasi antara pihak madrasah dengan pihak pondok berakibat pada mis komunikasi. Hal ini juga berakibat pada kurangnya motivasi peserta didik untuk melaksanakan kegiatan program madrasah.

Langkah yang diambil oleh madrasah dalam mengatasi kendala yang dihadapi dalam mengembangkan budaya sekolah berbasis pesantren adalah sebagai berikut: (1) Kepala madrasah melakukan penggiatan monitoring dan evaluasi atas pelaksanaan program untuk mengambil langkah dengan menempuh caracara yang lebih baik; (2) Perlahan-lahan melakukan pengoptimalan pengadaan sarana prasarana yang mendukung pelaksanaan program agar program berjalan sesuai dengan target; (3) pihak madrasah, khususnya bapak/ibu yang bersangkutan meningkatkan komunikasi dan koordinasi dengan pembimbing pondok agar terus memotivasi dan mendukung para santri dalam melaksanakan setiap program.

\section{SIMPULAN}

Setelah dilakukan penelitian, penyusunan hasil, dan pembahasan, maka kesimpulan dari karya ilmiah ini dapat diuraikan sebagai berikut:

Pertama, Pengembangan budaya sekolah berbasis pesantren di MTs Ali Maksum sebagai identitas atau karakteristik madrasah dengan berpedoman pada nilai-nilai kepesantrenan melalui sistem pendidikan dan pengajaran, kurikulum yang diterapkan dengan mengadopsi kurikulum Kemenag 100\% dan kurikulum pesantren $100 \%$, maupun program unggulan dan kegiatan ekstrakurikuler mampu meningkatkan motivasi belajar dan prestasi peserta didik.

Kedua, Pengelolaan budaya sekolah yang dikembangkan di MTs Ali Maksum menyertakan peran langsung kepala madrasah dengan melakukan kegiatan manajemen yang meliputi perencanaan, pengorganisasian, motivasi, dan evalusi melalui pembentukan tim yang bertanggungjawab menghandle kegiatan, penjadwalan, melakukan koordinasi langsung dengan bawahan dan pembimbing di pondok, serta melakukan peninjauan dan pengawasan baik secara langsung maupun tidak langsung sebagai pertimbangan dalam evaluasi.

Ketiga, Kendala yang dihadapi pihak MTs Ali Maksum dalam mengembangkan budaya sekolah adalah rendahnya kesadaran 
peserta didik maupun bapak/ibu guru terhadap pelaksanaan program; pelaksanaan program unggulan masih belum optimal karena merupakan program baru madrasah dan sarana prasarana belum memadai; dan kurangnya komunikasi dan koordinasi antara pihak madrasah dengan pihak pondok pesantren melalui pembimbing, sehingga motivasi peserta didik untuk melaksanakan program madrasah masih rendah.

\section{DAFTAR PUSTAKA}

Barnawi, A. (2013). Branded school. Membangun sekolah unggul berbasis peningkatan mutu. Yogyakarta: Ar-Ruzz Media.

Engkoswara, \& Komariah, A. (2010). Administrasi pendidikan. Bandung: CV Alfabeta.

Handoko. (2013). Administrasi pendidikan. Bandung: PT. Refika Aditama.

Hongboontri, C., \& Keawkhong, N. (2014). School culture: teachers' beliefs, behaviors, and instructional practices. Australian Journal of Teacher Education, 39(5). https://doi.org/10.14221/ajte.2014v39n5. 7
Kementerian Pendidikan dan Kebudayaan Republik Indonesia. (2014). Manajemen dan kepemimpinan sekolah. Bahan ajar implementasi Kurikulum 2013 untuk kepala sekolah. Jakarta: Pusat Pengembangan Tenaga Kependidikan, Kementerian Pendidikan dan Kebudayaan Republik Indonesia.

Pamuji, R. E., \& Prasojo, L. D. (2013). Pengaruh kepemimpinan transformasional kepala sekolah, motivasi kerja guru dan budaya sekolah terhadap kedisiplinan siswa di Kabupaten Bantul. Jurnal Akuntabilitas Manajemen Pendidikan, 1(1). Retrieved from https://journal.uny.ac.id/index.php/jamp/ article/view/2334

Presiden Republik Indonesia. Undang-Undang Republik Indonesia nomor 20 tahun 2003 tentang Sistem Pendidikan Nasional (2003). Indonesia.

Robbin, S. P. (1996). Perilaku organisasi: konsep, kontroversi, aplikasi. ( $\mathrm{H}$. Putjatmaka, Trans.) (1st ed.). Jakarta: Prenhallindo. 